\title{
Isoflavone in Postmenopausal Women - Are They Really Effective? A Prospective Case Control Study.
}

\author{
Bag TS, Kyal A, Saha DP, Dutta R, Mondal S \\ Medical College \& Hospital, Kolkata, 88, College Street, Kolkata - 700073
}

\begin{abstract}
A prospective case control study was conducted at Medical College, Kolkata with the aim of evaluating the role of isoflavone( a class of phytoestrogen -plant compounds having the beneficial effects of estrogen but lesser risks and side effects) in postmenopausal women. 100 postmenopausal women (those who underwent total abdominal hysterectomy and bilateral salpingooopherectomy for different benign indications, aged between $40-50$ years and who were menstruating before operation) were alternately distributed into two groups-Group $\mathrm{A}(\mathrm{n}=50$, received $60 \mathrm{mg}$ of isoflavone and $500 \mathrm{mg}$ of calcium per day for 6 months) and Group B (n=50, received 500mg of calcium per day only for 6 months). To evaluate the menopausal symptoms, the menopausal Kupperman index questionnaire was applied. Other outcomes measured were body mass index, blood pressure and lipid profile. Menopausal symptoms in Group A(those using isoflavones) were lower compared to Group B. The present study showed that Kupperman index decreased significantly in Group A (from $28.48 \pm 2.03$ to $16.32 \pm 1.06$ i.e. $45 \%$ decline) compared to Group B (from $24.56 \pm 1.52$ to $18.44 \pm 1.11$ i.e. $25 \%$ decline). No differences in blood pressure or body mass index were found during treatment between the two groups. In our study total cholesterol, triglycerides and low-density lipoproteins (LDL) decreased significantly in Group A compared to Group B. Therefore our clinical study indicates that isoflavone can be an invaluable resource for postmenopausal women for combating menopausal symptoms.
\end{abstract}

Keywords: Isoflavone, kupperman index, postmenopausal

\section{INTRODUCTION}

Estrogen replacement has long been therapy of choice for the treatment of climacteric symptoms in postmenopausal women as well as for the prevention of osteoporosis and cardiovascular diseases. ${ }^{1-3}$ However, prolonged exposure to unopposed estrogen increases the risk of endometrial hyperplasia and neoplasia. $^{3}$ Progestagen added with estrogen to decrease these risks can cause severe side effects in some patients. ${ }^{4,5}$ The identification of an alternative agent, which has the beneficial effects of estrogen but lesser side effects would be of considerable value. Isoflavones (a class of phytoestrogen) are plant compounds that are structurally or functionally similar to steroidal estrogens. The 3 major isoflavones found in soy (rich source of isoflavones) are genistin, daidzin, and glycitin. These compounds have both estrogenic and antiestrogenic activity. ${ }^{6,7}$ They function as pro-estrogens when estrogen deficiency is present and as antiestrogens when excess estrogen is present. If during menopause the body's natural level of estrogen drops, isoflavones can compensate this by binding to the estrogen receptor, thereby easing menopause symptoms as a result.

\section{METHODS}

The study was conducted at Gynaecology \& Obstetrics department of Medical College \& Hospital, Kolkata from 1st January 2010 to 31st December 2010.It was a prospective case control study where 100 postmenopausal women (those who underwent total abdominal hysterectomy and bilateral salpingo-oopherectomy for different benign indications, aged $40-50$ years and who were menstruating before operation) were alternately distributed into two groups-Group $\mathrm{A}(\mathrm{n}=50$, received $60 \mathrm{mg}$ of isoflavone and $500 \mathrm{mg}$ of calcium per day for 6 months) and Group $B(n=50$, received $500 \mathrm{mg}$ of calcium per day only for 6 months). In all cases written informed consent was taken and women with history of uncontrolled hypertension, stroke or transient ischemic attack, cancer diagnosed less than 5 years ago or previous myocardial infarction were

\section{CORRESPONDENCE}

Dr. Amit Kyal

Regent Court, Block 2, Flat-5D

V.I.P. Road, Kolkata-59, West Bengal, India

Phone: 9339108591

Email:amitkyal@yahoo.com 
excluded from the study. All subjects were not on any type of hormonal treatment during the previous 12 months and were also not using any lipid-lowering drugs, antidiabetic medications, soybean-derived products or herbal supplements. All women were queried about menopausal symptoms covered by Kupperman et al (1954) at the beginning of the study and at intervals of 3 and 6 months. The Kupperman index is a numerical conversion index and covers 11 menopausal symptoms: hot flashes (vasomotor), paraesthesia, insomnia, nervousness, melancholia, vertigo, weakness, arthralgia or myalgia, headache, palpitations and formication. Each symptom on the Kupperman index was rated on a scale from 0 to 3 for no, slight, moderate, and severe complaints. To calculate the Kupperman index, the symptoms were weighted as follows: hot flashes $(x$ $4)$, paraesthesias $(\times 2)$, insomnia $(\times 2)$, nervousness $(\times$ 2 ), and all other symptoms $(\times 1)$. Body mass index, blood pressure and lipid profile were recorded in all participants at baseline and at 3 and 6 months. Data collected were analyzed using standard statistical protocol.

\section{OBSERVATIONS}

A total of 100 postmenopausal women were alternately distributed into two groups-Group $\mathrm{A}(\mathrm{n}=50$, received $60 \mathrm{mg}$ of isoflavone and $500 \mathrm{mg}$ of calcium per day for ) and Group B(n=50,received 500mg of calcium per day only). Both the groups had similar age, parity and duration since menopause distribution (vide table 1).

Table 1. Comparison of age ,parity and duration since menopause

\begin{tabular}{lll}
\hline & $\begin{array}{l}\text { Group A } \\
\text { (Isoflavone and calcium) }\end{array}$ & $\begin{array}{l}\text { Group B } \\
\text { (Only calcium) }\end{array}$ \\
Age (years) & $45.00 \pm 3.33$ & $45.58 \pm 2.6$ \\
Parity & $2.96 \pm 0.19$ & $3.38 \pm 0.21$ \\
$\begin{array}{l}\text { Duration since } \\
\text { menopause(years) }\end{array}$ & $2.2 \pm 0.3$ & $1.94 \pm 0.2$ \\
\hline
\end{tabular}

Menopausal symptoms in Group A (those using isoflavones) were lower compared to Group B (vide table 2). Mean $\mathrm{KI}$ (Kupperman index) in Group A reduced from $28.48 \pm$ 2.03 to $16.32 \pm 1.06$ ( $p$ - value<.01) whereas in Group B it reduced from $24.56 \pm 1.52$ to $18.44 \pm 1.11$ ( $p$-value<.05) at the end of 6 months (vide table 2).There was no significant difference between blood pressure and body mass index between the two groups (vide table3). Total cholesterol, triglycerides and low-density lipoproteins (LDL) decreased significantly in Group A compared to Group B. Total cholesterol in Group A decreased from191.37 \pm 2.79 to $169.71 \pm 2.74 \mathrm{mg} / \mathrm{dl}$, triglycerides from $153.28 \pm 3.59$ to $130.68 \pm 4.40 \mathrm{mg} / \mathrm{dl}$ whereas low-density lipoproteins (LDL) from $119.48 \pm 2.83$ to $96.59 \pm 3.28 \mathrm{mg} / \mathrm{dl}$. In Group B total cholesterol decreased from $181.31 \pm 5.50$ to 180.35 $\pm 5.13 \mathrm{mg} / \mathrm{dl}$ whereas low-density lipoproteins (LDL) decreased from $109.27 \pm 5.88$ to $106.05 \pm 5.65 \mathrm{mg} / \mathrm{dl}$.The high-density lipoproteins (HDL) increased in both groups after treatment( vide table3).
Table 2: Comparative study of menopausal symptoms by Kupperman index

\begin{tabular}{|c|c|c|c|c|}
\hline & & 0 month & 3 months & 6 months \\
\hline \multirow{2}{*}{$\begin{array}{l}\text { Vasomotor } \\
\text { symptoms }\end{array}$} & Group A & $7.36 \pm 0.75$ & $5.92 \pm 0.70$ & $4.48 \pm 0.78^{* *}$ \\
\hline & Group B & $7.68 \pm 0.76$ & $7.04 \pm 0.70$ & $6.40 \pm 0.73^{*}$ \\
\hline \multirow[t]{2}{*}{ Paresthesias } & Group A & $4.24 \pm 0.31$ & $3.52 \pm 0.30$ & $2.48 \pm 0.24 * *$ \\
\hline & Group B & $3.52 \pm 0.17$ & $3.44 \pm 0.18$ & $3.04 \pm 0.26^{*}$ \\
\hline \multirow[t]{2}{*}{ Insomnia } & Group A & $3.12 \pm 0.55$ & $1.12 \pm 0.39$ & $0.96 \pm 0.23^{* *}$ \\
\hline & Group B & $3.22 \pm 0.55$ & $2.56 \pm 0.41$ & $2.19 \pm 0.17^{*}$ \\
\hline \multirow[t]{2}{*}{ Nervousness } & Group A & $2.16 \pm 0.54$ & $2.16 \pm 0.54$ & $0.48 \pm 0.15^{* *}$ \\
\hline & Group B & $1.92 \pm 0.39$ & $1.60 \pm 0.35$ & $1.28 \pm 0.28^{*}$ \\
\hline \multirow{2}{*}{$\begin{array}{l}\text { Depressed } \\
\text { Mood }\end{array}$} & Group A & $1.36 \pm 0.25$ & $1.16 \pm 0.21$ & $1.00 \pm 0.1^{*}$ \\
\hline & Group B & $0.88 \pm 0.16$ & $0.88 \pm 0.16$ & $1.00 \pm 0.2^{*}$ \\
\hline \multirow[t]{2}{*}{ Vertigo } & Group A & $0.84 \pm 0.26$ & $0.84 \pm 0.26$ & $0.84 \pm 0.26$ \\
\hline & Group B & $0.92 \pm 0.24$ & $0.92 \pm 0.24$ & $0.92 \pm 0.24$ \\
\hline \multirow{2}{*}{$\begin{array}{l}\text { Weakness/ } \\
\text { Fatigue }\end{array}$} & Group A & $2.80 \pm 0.10$ & $2.72 \pm 0.11$ & \multirow{2}{*}{$\begin{array}{l}2.48 \pm 0.12^{* *} * \\
2.08 \pm 0.1^{* *}\end{array}$} \\
\hline & Group B & $2.60 \pm 0.12$ & $2.32 \pm 0.13$ & \\
\hline \multirow{2}{*}{$\begin{array}{l}\text { Arthralgia + } \\
\text { Myalgia }\end{array}$} & Group A & $2.20 \pm 0.08$ & $2.16 \pm 0.09$ & $1.96 \pm 0.12$ \\
\hline & Group B & $2.68 \pm 0.10$ & $2.52 \pm 0.10$ & $1.96 \pm 0.16^{*}$ \\
\hline \multirow[t]{2}{*}{ Headache } & Group A & $1.36 \pm 0.27$ & \multirow{2}{*}{$\begin{array}{l}1.28 \pm 0.26 \\
1.20 \pm 0.24\end{array}$} & \multirow{2}{*}{$\begin{array}{l}0.32 \pm 0.56^{* *} \\
1.12 \pm 0.56\end{array}$} \\
\hline & Group B & $1.32 \pm 0.29$ & & \\
\hline \multirow[t]{2}{*}{ Palpitation } & Group A & $0.48 \pm 0.21$ & $0.44 \pm 0.19$ & $0.32 \pm 0.14$ \\
\hline & Group B & $0.32 \pm 0.14$ & $0.32 \pm 0.14$ & $0.32 \pm 0.14$ \\
\hline \multirow[t]{2}{*}{ Formication } & Group A & $0.24 \pm 0.12$ & $0.24 \pm 0.14$ & $0.20 \pm 0.13$ \\
\hline & Group B & $0.08 \pm 0.06$ & $0.08 \pm 0.06$ & $0.08 \pm 0.06$ \\
\hline \multirow[t]{2}{*}{ Mean KI } & Group A & $\begin{array}{l}28.48 \pm \\
2.03\end{array}$ & $24.64 \pm 1.49$ & $\begin{array}{l}16.32 \pm \\
1.06^{* *}\end{array}$ \\
\hline & Group B & $\begin{array}{l}24.56 \pm \\
1.52\end{array}$ & $22.52 \pm 1.27$ & $18.44 \pm 1.11^{*}$ \\
\hline
\end{tabular}

$* \mathrm{P}<0.05 ; * * \mathrm{P}<0.01$

Table 3: Comparative study of Lipid profile, body mass index and blood pressure

\begin{tabular}{|c|c|c|c|c|}
\hline & & 0 month & 3 months & 6 months \\
\hline $\begin{array}{l}\text { Serum } \\
\text { Cholesterol } \\
(\mathrm{mg} / \mathrm{dl})\end{array}$ & $\begin{array}{l}\text { Group A } \\
\text { Group B }\end{array}$ & $\begin{array}{l}191.37 \pm 2.79 \\
181.31 \pm 5.50\end{array}$ & $\begin{array}{l}184.58 \pm 3.12 \\
179.80 \pm 5.34\end{array}$ & $\begin{array}{l}169.71 \pm \\
2.74^{* *} \\
180.35 \pm \\
5.13\end{array}$ \\
\hline $\begin{array}{l}\text { Serum } \\
\text { Triglycerides } \\
\text { (mg/dl) }\end{array}$ & $\begin{array}{l}\text { Group A } \\
\text { Group B }\end{array}$ & $\begin{array}{l}153.28 \pm 3.59 \\
155.80 \pm 3.03\end{array}$ & $\begin{array}{l}143.92 \pm \\
4.15^{* *} \\
157.04 \pm 3.69\end{array}$ & $\begin{array}{l}130.68 \pm \\
4.40 * * \\
162.68 \pm \\
4.28\end{array}$ \\
\hline $\begin{array}{l}\text { Serum HDL } \\
\text { (mg/dl) }\end{array}$ & $\begin{array}{l}\text { Group A } \\
\text { Group B }\end{array}$ & $\begin{array}{l}43.58 \pm 1.41 \\
40.84 \pm 1.22\end{array}$ & $\begin{array}{l}43.96 \pm 1.52 \\
39.52 \pm 1.57\end{array}$ & $\begin{array}{l}44.84 \pm \\
1.36 \\
42.42 \pm \\
1.42\end{array}$ \\
\hline $\begin{array}{l}\text { Serum } \\
\text { LDL(mg/dl) }\end{array}$ & $\begin{array}{l}\text { Group A } \\
\text { Group B }\end{array}$ & $\begin{array}{l}119.48 \pm 2.83 \\
109.27 \pm 5.88\end{array}$ & $\begin{array}{l}109.99 \pm \\
3.04^{*} \\
108.72 \pm 5.92\end{array}$ & $\begin{array}{l}96.59 \pm \\
3.28^{* *} \\
106.05 \pm \\
5.65\end{array}$ \\
\hline $\mathrm{BMI}\left(\mathrm{kg} / \mathrm{m}^{2}\right)$ & $\begin{array}{l}\text { Group A } \\
\text { Group B }\end{array}$ & $\begin{array}{l}24.2 \pm 0.5 \\
25.4 \pm 0.6\end{array}$ & $\begin{array}{l}24.3 \pm 0.5 \\
25.4 \pm 0.6\end{array}$ & $\begin{array}{l}24.4 \pm 0.52 \\
25.6 \pm 0.6\end{array}$ \\
\hline $\begin{array}{l}\text { Max } \\
\text { B.P.(mm } \\
\mathrm{Hg})\end{array}$ & $\begin{array}{l}\text { Group A } \\
\text { Group B }\end{array}$ & $\begin{array}{l}133 \pm 3 \\
131 \pm 2\end{array}$ & $\begin{array}{l}133 \pm 2 \\
131 \pm 2\end{array}$ & $\begin{array}{l}133 \pm 2 \\
131 \pm 1\end{array}$ \\
\hline $\begin{array}{l}\text { Min } \\
\text { B.P. }(\mathrm{mm} \\
\mathrm{Hg})\end{array}$ & $\begin{array}{l}\text { Group A } \\
\text { Group B }\end{array}$ & $\begin{array}{l}84 \pm 2 \\
84 \pm 2\end{array}$ & $\begin{array}{l}84 \pm 2 \\
84 \pm 2\end{array}$ & $\begin{array}{l}84 \pm 1 \\
85 \pm 1\end{array}$ \\
\hline
\end{tabular}

$* * P<0.01 ; * P<0.05$ 


\section{DISCUSSION}

Most women experience some effects of estrogen deficiency during menopause. Effects range from shortterm discomfort to long-term changes that can have a profound effect on a woman s health. The present clinical study was done to evaluate the short-term effects of soy isoflavones (which is a class of phytoestrogen that are structurally or functionally similar to steroidal estrogens but with lesser side effects) in postmenopausal women. In our study, a total of 100 postmenopausal women were alternately divided into two groups-Group $A(n=50$, received $60 \mathrm{mg}$ of isoflavone and $500 \mathrm{mg}$ of calcium per day) and Group $B(n=50$, received $500 \mathrm{mg}$ of calcium per day only).In our study the average age of women was approximately 45 years with average time since menopause ranging from 2 to 2.2 years. The age at menopause in our study was similar to the earlier studies which have reported menopause at 43 to 49 years in developing countries. ${ }^{8,9}$ The present study showed that Kupperman index decreased significantly in Group A (from $28.48 \pm 2.03$ to $16.32 \pm$ 1.06 i.e. $45 \%$ decline) compared to Group B (from 24.56 \pm 1.52 to $18.44 \pm 1.11$ i.e. $25 \%$ decline) Our findings are in contrast to earlier report by Germain et al where no improvement in menopausal index was seen with either soy proteins or soy isoflavones after 24 weeks. ${ }^{10}$ However, Murkies et al have demonstrated significant decrease in menopausal symptoms in soy supplemented group within 6 weeks as compared to wheat flour group..$^{11}$ In our study total cholesterol, triglycerides and low-density lipoproteins (LDL) decreased significantly in Group A (Total cholesterol decreased from $191.37 \pm 2.79$ to $169.71 \pm 2.74 \mathrm{mg} / \mathrm{dl}$, triglycerides from $153.28 \pm 3.59$ to

$130.68 \pm 4.40 \mathrm{mg} / \mathrm{dl}$ and low-density lipoproteins (LDL) from $119.48 \pm 2.83$ to $96.59 \pm 3.28 \mathrm{mg} / \mathrm{dl}$ ) compared to Group B (total cholesterol decreased from181.31 \pm 5.50 to $180.35 \pm$ $5.13 \mathrm{mg} / \mathrm{dl}$, low-density lipoproteins (LDL)decreased from $109.27 \pm 5.88$ to $106.05 \pm 5.65 \mathrm{mg} / \mathrm{dl}$ whereas triglycerides increased from $155.80 \pm 3.03$ to $162.68 \pm 4.28 \mathrm{mg} / \mathrm{dl}$. Numerous other clinical studies have shown that soy protein can cause significant reduction in serum total cholesterol, LDL-Cholesterol and triglycerides. ${ }^{12,13,14}$ Isoflavones as part of soy protein have been postulated to account for the hypocholesterolemic effect of soy protein. ${ }^{15-17}$ However, several other investigations also do not support the hypocholesterolemic role of soy isoflavones. ${ }^{12,18-20}$ Therefore our clinical study indicates that isoflavone can be an invaluable resource for postmenopausal women for combating menopausal symptoms.

\section{CONCLUSION}

Estrogen replacement has long been considered as therapy of choice for the treatment of climacteric symptoms in postmenopausal women but estrogen has numerous side effects and prolonged exposure to unopposed estrogen also increases the risk of endometrial hyperplasia and neoplasia . Isoflavones (a class of phytoestrogen) act as selective estrogen enzyme modulators functioning as pro-estrogens when estrogen deficiency is present and as antiestrogens when excess estrogen is present and they delicately balance the estrogen metabolism in the body. Our clinical study indicates that isoflavones can be of great use for combating menopausal symptoms in postmenopausal women and can be effectively used as an alternative agent, which has the beneficial effects of estrogen but considerable lesser risks and side effects when compared to estrogen.

\section{REFERENCE}

1. Thorneycroft IH. Practical aspects of hormone replacement therapy. Prog Cardiovasc Dis. 1995;38(3):243-54.

2. Ettinger B, Friedman GD, Bush T, Quesenberry CP Jr. Reduced mortality associated with long-term postmenopausal estrogen therapy. Obstet Gynecol. 1996;87(1):6-12.

3. Boroditsky RS. Balancing safety and efficacy focus on endometrial protection. J Reprod Med. 2000;45(Suppl 3):273-84.

4. Whitehead MI, Townsend PT, Pryse-Davies J, Ryder T, Lane G, Siddle N, King RJ. Actions of progestins on the morphology and biochemistry of the endometrium of postmenopausal women receiving low-dose estrogen therapy. Am J Obstet Gynecol. 1982;142(6 Pt 2):791-5.

5. Perry C, Berliner S. Progesterone and the risk of arterial and venous thrombosis. Harefuah. 1998;134:633-7.

6. Miksicek RJ. Estrogenic flavonoids: structural requirements for biological activity. Proc Soc Exp Biol Med. 1995;208(1):44-50.

7. Cassidy A, Bingham S, Setchell K. Biological effects of isoflavones in young women: importance of the chemical composition of soyabean products. Br J Nutr. 1995;74:587-601.

8. Sethi HK, Sidhu LS, Singal P. Menopausal age and related factors. In: Human Biology Global Development. L.S. Sindhu and S.P.Singh (Eds). USG Publishers and Distributors. Ludhiana 1996, page 13751.

9. Neslihan CS, Bilge SA, Ozturk TN, Oya G, Ece O, Hamiyet B. The menopausal age, related factors and climacteric symptoms in Turkish women. Maturitas. 1998;30(1):37-40.

10. Germain A, Peterson C, Robinson J, Alekel L. Isoflavone-rich or isoflavone-poor soy protein does not reduce menopausal symptoms during 24 weeks of treatment. Menopause. 2001;8(1):17-26.

11. Murkies AL, Wilcox G, Davis SR. Phytoestrogens. J Clin Endocrinol Metab. 1998;83(2):297-303.

12. Baum JA, Teng H, Erdman JW, Weigel RM, Klein BP, Persky VW, et al. Long-term intake of soy-protein improves blood lipid profiles and increases mononuclear cell low-density lipoprotein receptor messenger RNA in hypercholesterolemic postmenopausal women. Am J Clin Nutr. 1998;68:545-51.

13. Hermansen K, Sondergaard M, Hoie L, Carstensen M, Brock B. Beneficial effects of a soy-based dietary supplement on lipid levels and cardiovascular risk markers in type II diabetic subjects. Diabetes Care. 2001;24(2):228-33.

14. Tonstad K, Smerud KT, Hoie L. A comparison of effects of 2 doses of soy protein or casein on serum lipids, serum lipoproteins, and plasma total homocysteine in hypercholesterolemic subjects. Am J Clin Nutr. 2002;76:78-84.

15. Merz-Demlow BE, Duncan AM, Wangen KE, Xu X, Carr TP, Phipps WR, Kurzer MS. Soy isoflavones improve plasma lipids in normocholesterolemic, premenopausal women. Am J Clin Nutr. 2000;71(6):1462-9. 
16. Gardner CD, Newell KA, Cherin R, Haskell WL. The effect of soy protein with or without isoflavones relative to milk protein on plasma lipids in hypercholesterolemic postmenopausal women. Am J Clin Nutr. 2001;73(4):728-35.

17. Crouse JR 3rd, Morgan T, Terry JG, Ellis J, Vitolins M, Burke GL. A randomized trial comparing the effect of casein with that of soy protein containing varying amounts of isoflavones on plasma concentrations of lipids and lipoproteins. Arch Intern Med. 1999;159(17):2070-76.

18. Nestel PJ, Yamashita T, Sasahara T, Pomeroy S, Dart A, Komesaroff $\mathrm{P}$, Owen A, Abbey M. Soy isoflavones improve systemic arterial compliance but not plasma lipids in menopausal and perimenopausal women. Arterioscler Thromb Vasc Biol. 1997;17(12):3392-8.
19. Sirtori CR, Gianazza E, Manzoni C, Lovati MR, Murphy PA. Role of isoflavones in the cholesterol reduction by soy proteins in the clinic. Am J Clin Nutr. 1997;65(1):166-7.

20. Greaves KA, Wilson MD, Rudel LL, Williams JK, Wagner JD. Consumption of soy protein reduces cholesterol absorption compared to casein protein alone or supplemented with an isoflavone extract or conjugated equine estrogen in ovariectomized cynomolgus monkeys. J Nutr. 2000;130(4):820-26. 